\title{
The Development of Information Literacy in Increasing the Quality of Higher Education Learning
}

\author{
Elva Rahmah and Desriyeni \\ The Study Program of Information, Library, and Archive \\ Universitas Negeri Padang \\ Padang, Indonesia \\ elva@fbs.unp.ac.id, desriyeni@yahoo.com
}

\begin{abstract}
Development of information literacy in universities is packed into various activities aimed at improving the quality of learning in universities. The quality of learning is related to the ability to identify, seek, find, evaluate, and utilize information. This ability is called information literacy. Therefore, through this information literacy program, students are expected to become competent and independent individuals. In addition, students are also able to solve the problem of information found. Through the competency standard of information literacy, students can define their information needs, obtain information needed effectively and efficiently, evaluate and select information according to their needs, use information to achieve their objectives and use information according to ethics and legally. Thus, students can adapt to change and can produce scientific works that meet international standards. The issues that will be discussed in this paper are (a) the importance of information literacy in universities; (b) the competence of student information literacy; and (c) information literacy activities in universities.
\end{abstract}

\section{Keywords: information literacy; learning; competence literacy information}

\section{INTRODUCTION}

The impact of the development of information technology led to an explosion of information; anyone could receive any information, without any limit of space and time. For that reason, anyone needs to have knowledge in finding and obtaining the right information in order to meet their needs. This is due to the nature of information as an entity that has the potential to become a power and also source of confusion for many people. Every day, each person is challenged to deal with huge portion and speedy movement of information, as well as in countless formats.

Information is a necessity that must be possessed by everyone, because information has lately become a primary requirement of each individual, especially in the world of education. One of them is within the scope of higher education (college). Students are required to obtain information in the form of learning materials related to course to uphold and to support their lectures or in other words, to develop and to expand the subject matter by themselves. When they want to find information quickly, precisely and accurately, then the students must have certain ability in obtaining the information. In order to succeed the process of meeting the needs of information, then it is very necessary that students to understand about information literacy or then it is mandatory that students understand information literacy or which are also called information-wise.

The ability to identify, to seek, to discover, to evaluate and to utilize information is called as information literacy. The concept of information literacy according to Reitz (2004: 356) is defined as skill in finding the information one needs and understanding of how libraries are organized, familiarty, with resource the provide (including information formats and automated search tools) nad knowledge of commonly use techniques. The technological insfrastructure on which information transmission is based, including its social, and cultural context and impact.

Based on educational perspective, information literacy according to Bruce, (2003: 3) is information literacy defines as the ability-solve, make decisions in formal and informal learning contexts, at work, at home and in educational settings.

The definition of an information evolves with the development of technology for that information. In addition, the concept is also the result of adaptation and development of educational institutions, professional and personal organizations. Various information formatsand the term information is also not just a print-out,so that the concept of visual, computer, digital, networkbecame the scope of literacy studies as well.

The term information literacy is not a new science which emerged as a demand in the information age. The need for mastering this ability has existed since many years ago, only the quantity and form of information that changed according to the development of science and technology. Although the need to search, evaluate and use the needed-information effectively has existed for a long time, but a must-have capability in today's information age continues to grow and become more intricate.

In the context of library and information, information literacy according to Hasugian (2008: 35-36), always associated with the ability to access and make the correct use of a number of information available both within the library and outside of the library building. In addition, information literacy according to Hasugian (2008: 36) is a series of capabilities that a person needs to be aware when information is needed and have the ability to search, communicate that information effectively. 
Pendit (2008: 119) states that the capabilities of user communities which want to be empowered as follows: (1) establishes the nature of the range of information required, (2) accessing the information needed effectively and efficiently, (3) critically evaluating the information and its sources, and (4) using information for a particular purpose.

Thus, students are required to have the ability of information literacy. By having the ability of information literacy students know when and why they need an information, then know how and where to get that information, able to evaluate whether the information obtained is correct,and finally ready to use it and present it correctly.

Through information literacy skills, students can use information to solve problems and make decisions using various sources of information,both printed sources and computer-based information sources. Moreover, students are able to adapt to a new technology and can learn independently throughout their life.

All those skills are important and those skills are part of the information literacy. Maybe all this time, a collegewas aware of the skills or abilities that students need to have to be able to learn independently, but did not realize that the skills presented were not sufficient for the students to do it by themselves. So in the instructional process, students often get difficulties in understanding the instruction given by the lectureruntil what they do does not meetwith the given task/instruction.

In fact, many students find it difficult to find ideas for a paper, in a particular topic or research ideas for their final assignment. On the other hand, there are still many students who have difficulty in getting a source of information,so the source of information is less varied and tends to use a cliche source or typical format. On the other hand, it takes great effort to change student's habits to quote only single literature in writing their paper and the capabilityof information literacy required to prevent unwillingness of information coming from the internet. The problem to be discussed in this paper wasthe importance of information literacy in university, competency of students' information literacy, and information literacy activities in university.

\section{METHOD}

To see and get an overview of the development of information literacy in improving the quality of college learning, in accordance with the problems discussed methods used are qualitative methods. Data collection is done through observation, interview and document analysis. Subjects in this research are lecturer, library head, librarian and student, events, facts, documents and various forms of efforts, programs or library activities. The object of the research is the development of information literacy in improving the quality of learning in Universitas Negeri Padang.

\section{FINDING AND DISCUSSION}

\section{A. The Importance of Information Literacy in Higher Education}

The availability of many information resources in the college library will be useless if not followed by the ability to utilize the information resources.Information literacy in universities can be applied in all fields of science with an emphasis on searching, finding and using information. A wide variety of information options are available both print and non-print, making information literacy very important in the age of information.In addition, the learning process is very influential to transform an information into a knowledge.

Information literacy ability in library services not only needed to optimize the use of library resources in teaching, learning and research, but also to train users to get to know the sources of information and find the actual information from various electronic sources available (Mishra \& C, 2010).

Competency standards related to information literacy are widely developed by various library associations in some developed countries. Many renowned colleges have adopted the principles and standard of literacy for their needs. The movement of information literacy in the college environment has also been supported by several university accrediting boards and higher education by applying assessment standards related to the information literacy program to support the teaching (Association of College \& Research Libraries (ACRL) (Libraries, Information Literacy and Accreditation Agencies, 2011)

There are several standards of information literacy competence are already popular and developed by a library association designed specifically for colleges that is Association of College and Research Libraries (ACRL) which is a division of American Library Association (ALA) and The Society of College, the National and University Libraries (SCONUL) of the United Kingdom and Ireland. ARCL establishes 5 information literacy standards accompanied by performance indicators of each standard and accompanied by results, This standard consists of Know, Access, Evaluate, Use and Ethical / Legal (Association of College \& Research Libraries (ACRL), (Association, 2000). SCONUL establishes the model by using the seven pillars of information literacy. These pillars consist of Identify, Scope, Plan, Gather, Evaluate, Manage, and Present (SCONUL (The Society of College, National and University Libraries) (the Society of College, 2011).

Through this information literacy program, students are expected to become skillful students and independent students. They can identify their information needs and capturing the wandering ideas. In addition, students are also able to solve the problem of information they have. Through the competence standards of information literacy owned by students, they are able to define their information needs, to obtain the information needed effectively and efficiently, to evaluate and to select information according to their needs, to use information to achieve their goals, and to utilize information according to ethics and legally. So that students can adapt to a change and can produce scientific works that meet international standards. 
UNESCO (2005: 1) states that information literacy gives a person the ability to interpret informationas an information user and become an information producer for him/herself. The goals of literacy according to UNESCO are (1) to provide a person with the skills to be able to access and to obtain information about health, environment, education, work and so forth; (2) to guide them in making the right decisions about their lives and (3) to be more responsible for their health and education.

Information literacy programs need to be conducted in the college library for several reasons. First, the ability of students in utilizing the library is a fundamental in achieving the success of an education. Second, the library is expected to be able to educate student to become a compliant and responsible librarian. Third, the library strives for all assets in the form of collections, both in the form of printed and recorded, with all facilities and services can be fully utilized by the user.

Hancock (2004: 1) stated that the benefit of literacy for learners is they know how to master some lessons in instructional process and reduce their dependence on teacher's attendance because they can learn independently by maximizing the ability of information literacy. This can be seen from their appearance and activities in the learning environment. The student, who is literate, will try to learn about various resources of information and how to use information sources.

According to the American Library Association (in Naibaho, 2007: 6) in developed countries such as United States, some disciplines considered information literacy as the main outcome of student's learning in college because building a lifelong learner is a major mission of higher education. Through an information literacy program, education ensures that every individual obtains the intellectual ability to think and argue critically, as well as learn knows how to learn in the right way. Because of this factor, information literacy is always related to lifelong learning. Furthermore, Chan Yuen Chin (in Naibaho, 2007: 6) said that (a) information literacy is essential to the success of lifelong learning, (b) information literacy is a major competence in the age of information, and (c) information literacy contributes to the development of teaching and learning.

Literacy skills are important and beneficial to everyone in the age of information, especially for students. Every learner who masters information literacy can create new knowledge and can combine it with the previous knowledge that he/she has owned hence, making it easier to make a decision or a policy.

\section{B. Competency of Student's Information Literacy}

Information literacy competence is a person's literacy ability measured based on several performance indicators contained in the information literacy standard. One can be called to have the competence of information literacy if she/he meets the required standard. There are several standards created by library organizations from different countries such as Association of Colege\& Research Libraries and The Australian and New Zealand Institutions for Information Literacy.

The competency of student's information literacy at the college is formulated by the Association of College and Research Libraries (in Hasugian, 2008: 38-39). It consists of five standards and twenty indicators as follows. First, determining the nature and scope of the information required. This can be seen from the indicators of the student's ability in defining information needs, identify various types and formats from potential sources of information, consider the costs and benefits of the search of information needed, and re-evaluate the nature and scope of information needed.

Second, accessing the information needed effectively and efficiently. This can be seen from the ability of selecting searching methods or the most appropriate information retrieval system to find the required information, constructing and implementing an effective searching strategy, rediscovering information on-line or privately by using a variety of methods, changing searching strategy if necessary and citing, recording and processing information and its resources.

Third, evaluating information and sources critically. This can be seen from the ability of students to summarize the main ideas that can be followed from the information collected, issuing and using initial criteria to evaluate information and its sources, collecting key ideas to build new concepts, comparing new knowledge with prior knowledge to determine information's extra value, contradiction, and other unique characteristics, deciding the impact of new knowledge on a person's value system and determining how to unify the differences, proving the accuracy of understanding and interpreting information through discussions with other individuals, experts or practitioners, and determining whether the original question needs to be revised.

Fourth, using information to accomplish certain goals. This is derived from the ability to use new and past information for planning and creating special results or performance, revising the development process for results or performance, and to communicate results or performance effectively to others.

Fifth, understanding the economic, legal and social aspects related to the use of information. This can be seen from student indicators in understanding the economic, legal and socio-economic issues surrounding information and information technology, following the rules/laws as well as the institutional and ethical policies relating to access and the use of information resources along with appreciating the use of information resources in communicating products or performance.

In the digital age, the five student's literacy competencies above are required because the source and location of the literature is more diverse. The literature sources include libraries, web sites, mass media, government agencies and private institutions and social media. However, libraries remain a more legitimate source due to the assurances of the author and publisher, in the sense of more accountable truth. However, it does not merely make non-library literature such as internet becomes invalid. Having said that literature sourced from the internet needs to be verified more thoroughly in order that invalid literature is not used in scientific papers or used as a reference in making course's assignments. Therefore, the competence of information literacy is vital in higher education. The world of education must recognize the importance of information literacy 
should continue to be studied so as the learning process can be well conducted. Students are required to obtain information to support and to uphold the learning activities by developing and extending course material independently.

\section{The Activity of Information Literacy at University}

A university should be aware of the importance of information literacy, because this capability cannot be obtained in agreement with the process of instructional in higher education. Mostly, university generally only provides students with literacy skills related to library activities such as how to find and to access information. In addition, there are some skills that can be learned in the library such as how to use library collection and to utilize library services along with searching online articles on library-subscribed databases.

That situation should be a challenge for a university to prove that information literacy is a compulsory ability for all students. Information literacy is the main point in improving students' knowledge. Through activity of information literacy, students are able to learn independently and able to deal with various sources of information and able to execute effective lifelong learning. Therefore, university as education provider needs to create an information literacy training program for students.

Implementation of information literacy in university can be done through various activities. First, introduction of campus life for new students (PKKMB) with material explanations related to library-referenced exploration based on information technology. This material explains everything about the literature, from the type of literature, its sources and the way it is searched.

Second, it can be included in the course, either non-counted course or counted-in course which is integrated in the curriculum. Literacy instructional can be conducted in the classroom by involving associated lecturers and reliable librarians as educators. Through this activity, students can share their knowledge through the learning process where students and lecturers can share or exchange knowledge among them. This exchanged process is able to create a new knowledge which may possibly be updated from time to time. In addition, by possessing information literacy skills, students are able to think critically and logically and not easily believe in any information, therefore, being able to evaluate any information before use.

As Behrens (1994) points out, library involvement in curriculum development should be implemented through an integrated education program with the curriculum and aimed to form students who are literate in the field of information. For that according to (Ragains, 2003), the library can establish cooperation with faculty in the implementation of information skills activities in the curriculum. He considered that librarians should act as subject specialists for that, he suggests the library to be a link between subject and specialization.

It teaches the information literacy model supported by various printed information sources. It also teaches how to read effectively, to write correctly according to the certain rules, to cite and to use printed-information sources. The literacy modules are simple and interesting can be made in printed form such as pocket books and attractive posters.

Thirdly, information literacy programs are included in library-user education as a requirement in obtaining library member cards. College libraries generally only provide students with literacy skills related to library activities such as how to search and to access information.

Several skills that can be obtained in library are how to use collections and to take advantage of library services, along with searching online articles on library-subscribed databases. Librarians should teach users to manage information with new technology applications which is integrated with the curriculum in college to achieve optimal results. The information literacy training program can be given once at the beginning of the lecture or twice in separate times. The content of the material can be divided into introduction to literacy and advanced literacy.

In addition, information tracing can be supported with computer skills and management of scientific writing or information products by using the appropriate computer software. Information literacy modules can be provided on $\mathrm{CD}$ or available in the form of a file or computer application. In addition, information literacy modules can be presented on the library site which can be accessed anytime and anywhere, including in the library computer room. With the presence of a computer room in a library, supervision by the librarian can be conducted when it is needed.

The skills mentioned above should be supported by the essential skills that students need to have such as basic skills about empowerment of library, knowledge, and the use of information technology. Rapid change and very dynamic development of an era only can be followed by mastering of information literacy supported by information technology. Thus, urgent need of literacy skills in the educational environment especially in higher education is irrefutable in order to create a literate generation.

Information literacy skills will be owned by students after doing several processes, among others (1) defining information. It is closely related to the accuracy of information in answering and assisting students in completing tasks; (2) finding information. This includes students' knowledge in identifying different types of information sources and knowing where the information can be found; (3) selecting information. The process of selecting information is done by the students by selecting relevant information, so that the information needed can be used immediately; (4) Processing information. Students can distinguish between facts from the diversity of information and the students know exactly the amount of adequate information to be used; (5) Presenting information. This includes the ability of students to distribute information and transforming information in different format from the original; (6) accessing information. This includes the reflection on the success that students have been achieved. Thus, it can determine the strategic steps for future development. 
The benefits of information literacy according to Adam (2009: 1) are (1) helping to make decisions. Information literacy plays an important role in solving problems and determining decisions to be taken; (2) creating educated human in the age of information. The more skilled a person to seek, to find, to evaluate and to uses the information, so as the more open the opportunity to always do learning independently; (3) creating new knowledge. Someone is categorized as success in learning if she/he able to create brand new knowledge.

The challenges in applying information literacy in universities are as follows (1) unawareness of the leaders of the institution about the importance of information literacy even assuming that ability can be easily obtained in accord with the instructional process at universities, (2) the limited role of the librarian; they were still at a stage of development which requires the development of continuous collaboration through the support of third party in the university and (3) no standard of information literacy has been developed to apply in college.

\section{CONCLUSION AND RECOMMENDATION}

Information literacy is very useful in the college society to support the learning process and implementing competencybased curriculum which requires students to find information for lecturing affairs and able to utilize various sources of information. By applying the concept of information literacy, it can guide students in comprehending the learning process as a whole and in the future, enables them to do independent learning. To measure the competence of students' information literacy in the university, then the Association of College and Research Libraries standards may be utilized by using twenty indicators. The standard of information literacy for student's learning provides a complete conceptual framework and complete guidelines in order to explain the information literacy to the students.

\section{References}

Adam. (2009). Literasi Informasi. Dipetik August 12, 2017, dari Perpustakaan UMY: http://perpus.umy.ac.id/2009/02/19/literasi-informasi

Libraries, A. o. (2000). Information Literacy Competency Standards for Higher Education. Dipetik November 10, 2017, dari Association of College \& Research Libraries: http://www.ala.org

Behren, S. J. (1994). a Conceptual Analysis and Historical Overview of Information Literacy. College \& Research Libraries, 56, $309-332$

Bruce, C. (2003). Seven Faces of Information Literacy: Towards Inviting Students into New Experiences. Dipetik August 10, 2017, dari Archive : http://crm.hct.ac.ae/events/archive/2003/speakers/bruce.pdf.

Hancock, V.E (2004). Information Literacy for Lifelong Learning. Dipetik September 11, 2017, dari Ericdigests: http://www. ericdigests.org/lifelong.htm

Hasugian, J. (2008). “UrgensiLiterasiInformasidalamKurikulumBerbasisKompetensi di PerguruanTinggi”.Pustaha: JurnalStudiPerpustakaandanInformasi, 4 (2), 34-44.

Libraries, A. o. (2000). Information Literacy Competency Standards for Higher Education. Dipetik November 10, 2017, dari Association of College \& Research Libraries: http://www.ala.org

Libraries, A. o. (2011). Information Literacy and Accreditation Agencies. Dipetik November 10, 2017, dari Association of College \& Research Libraries : http://www.ala.org

Mishra, R., \& C, M. (2010). Relevance of Information . Dipetik November 11, 2017, dari Journal of Emerging Trends in Computing and Information Sciences: http://www.cisjournal.org

Naibaho, K.( 2007). "MenciptakanGenerasiLiteratMelaluiPerpustakaan". VisiPustaka, 9 (3), 1-15.

Pendit, P. L. (2008). Perpustakaan Digital dariAsampai Z. Jakarta: CitaKaryakarsaMandiri.

Ragains, P. (2003). Information Literacy Instruction that Works: a Guide to Teaching by Discipline and Student Population. Neal-Schuman, 1-6.

Reitz, J. M. (2004). Dictionary for Library and Information Science. Westport: Libraries Unlimited.

The Society of College, N. a. (2011). The SCONUL Seven Pillars of Information Literacy Core Model for Higher Education. Dipetik November 12, 2017, dari SCONUL Working Group on Information Literacy : www.sconul.ac.uk

.United Nations Education, S. a. (2005/2008). Information for All Programme (IFAP): Towards Information Literacy Indicators. Dipetik August 15, 2017, dari UNESCO: http://www.uis.unesco.org/templated/pdf/cscl/InfoLit.pdf 